Johanna Domokos \& Michal Kovár

\title{
Terveisiä Lapista as an Example of Intercultural Dialogism ${ }^{1}$
}

In the late 1960s and early 1970s, literary voices of indigenous and postcolonial emancipation made a breakthrough in many national book markets. It was a time when many talented authors used their work to protest the hegemonic mechanisms by which many social and ethnic minorities were marginalized. Written mostly in majority languages, books like Jean Rhys's Wide Sargasso Sea (1966), M. Scott Momaday's House Made of Dawn (1968), Dee Brown's Bury my Heart at Wounded Knee (1970), and Nils-Aslak Valkeapääs Terveisiä Lapista (1971) were published by major publishing companies. Several of these books received widespread recognition in the form of literary prizes, and they have opened the way to thriving literary movements, which today have progressed to their third or fourth waves. The voices of the oppressed from this time can be accurately described in terms of three processes set forth by Suzanne Lunquist (2004) in her introduction to Native American Literatures. According to Lundquist, these authors work towards: (1) legitimizing their cultural heritage through literary expression, (2) rediscovering and re-evaluating earlier texts by their ancestral authors and sympathetic anthropologists, and (3) renewing interest in traditional artistic expressions such as oral literature, ceremonialism, and song traditions.

With the goal of achieving emancipation for indigenous and colonized peoples, many writers began their careers by publishing in colonial languages, and then reverted to their mother tongues in later works. Examples include Ngũgĩ wa Thiong'o, who switched from English to Gikuyu, and Kirste Paltto and Nils-Aslak Valkeapää, who began writing in Finnish before they have switched to North Sámi. Valkeapää (Áilu or Áillohaš in Sámi environment) was the first writer in Finnish literary history to draw readers' attention to the issues of Finnish colonialism, ${ }^{2}$ a topic that has gained particular relevance in Finnish discourse today (see Keskinen et al.2009; Lehtola 2012 or the 2014; Ihme Days in Kiasma, ${ }^{3}$ and the discussion on Finnish colonialism at the 2014 Frankfurt Book Fair $\left.{ }^{4}\right)$.

\section{Call for intercultural dialogue}

Nils-Aslak Valkeapääs literary debut Terveisiä Lapista (1971) is a polemical work that provides a rousing description of how "cultures" were constructed and brought into hierarchical order in Northern Europe over the past century. ${ }^{5}$ Rather than just educate or delight, the book was written with the purpose of protesting against the way Sámi 
people were treated by their colonizers and to incite members of majority to discuss. Valkeapää conveyed his message in the dialogic genre of a political pamphlet. ${ }^{6}$ About the reasons of producing his 1971 book, Valkeapää confesses in the Author's Introduction to the English translation the following:

At the time that I wrote Greetings from Lapland, my intention was to act as a sort of initiatior for discussion. The idea was to write so as to cause controversy, and to create an urge in people to get involved, argue. And a discussion did get started, to some extent. [--] Originally then, I wrote the book as an introduction to a debate about the Samis' situation in Finland. The text was relevant to the time, and took up a number of topics which were 'in the air' at that point. (Greetings from Lapland, 1, 2; from now on GL.)

Expressing his resentment and advocating intercultural reflection, Valkeapää addresses a number of distinct publics at once: a larger public composed of those not possessing enough knowledge on Sámi matters, but willing to get an insider view; the community of powerful (President, Ministers and other politicians) from whom the author awaits change; members of the author's own ethnicity (the Sámi); and like-minded individuals be it from other indigenous communities or any other sympathising interest group (like people from the ecological movements). With the number of translations the original Finnish pamphlet got in the lifetime of the author, this polemical writing was reshaped for including a wider horizon of the addressed - other majority societies where Sámi were living, up to the global audience. Valkeapää attests in the English edition:

With the passing of the years, new and current matters have arisen whilst earlier ones have been forgotten, including those which were 'in the air' then, and which have naturally been completely supplanted by new ravages. For this reason a good deal of the original text has been left out, but there may still be many things which are difficult to comprehend, seen in a world-wide perspective. I can only ask humbly to be excused. Maybe I'll have to write a whole new book sometime. (GL, 2-3.)

Thematically, Valkeapää's provocative narrative can be divided into four sections. The first section contains chapters with titles referring to "essential" Sámi cultural phenomena, e.g. "Arktinen kulttuuri" ("Arctic culture"), "Lappi" ("Lapland"), "Saamelainen" ("Sámi"), "Suopunki" ("Lasso"), "Lumikelkka" ("Snowmobile"), and "Joiku" ("Yoik"). The second section consists of chapters with titles referring to broader cultural phenomena and concepts, such as "Matkailija" ("Tourist"), "Koulu" ("School"), "Kristus" ("Christ"), and "Äidin kieli" ("Mother Tongue"). These chapters focus on contradicting the Finns' negative attitudes toward the Sámi, as well as placing Sámi history in a positive light and describing fundamental elements of Sámi culture that have been extremely misunderstood, misinterpreted, and consequently disrespected by majority cultures. The third section comprises the chapters "Nat Turnerin kapina" ("Nat Turner's Rebellion") and "Jälkikirjoitus" ("Post Scriptum"), while the fourth 
section ("Anna Liisa") is an ironic letter to Anna-Liisa Tiekso, Finland's leftist minister of social affairs from Finnish People's Democratic League at the time. Only this letter is written in the North Pohjanmaa dialect of Finnish, the distinctive feature of a "genuine Finn" in Finnish literature; all other parts of the book are written in the standard Finnish literary language.

By placing this Nordic cultural clash into a larger global context, the third chapter of the book echoes the hegemonic treatment of Native American and other postcolonial peoples. This chapter consists of three subsections, and in spite of its title, it provides just a succinct description of the case of the slave rebellion leader Nat Turner (1800-1831). Stylistically this section of the book is closer to a scholarly narrative, constructed with many quotations and a simple topic-comment structure, presenting cultural values and ethics as relative. This particular type of narrative strategy is predicated on the author's intended addressee: each part of the text intended for a Finnish majority reader (or, indeed, for any member of Western civilization) is marked by the simulation or imitation of scientific language and dialogues. The ironic and sometimes overtly satirical tone of these passages brings the work closer to the genre of a pamphlet. Conversely, in the parts of the text where the implied reader is Sámi (or any indigenous person), the writing style is more fluent and observational. These contrasting styles balancing between eloquence and plain style are kept better separate for the first two parts of Terveisiä Lapista, while in the remainder of the text - especially "Nat Turner's Rebellion" - they are closely intertwined.

\section{Narrative strategies in Terveisiä Lapista}

In several of his works Michail Bakhtin (1929, 1934, 1963) drew our attention not only to the continual communication of the dialogic works with other texts, but also to the interaction of various registers and languages of the novelistic discourse. In his essay "Slovo v romane," (translated as "Discourse in the Novel") Bakhtin explains:

Any concrete discourse (utterance) [--] is shot through with shared thoughts, point of view, alien value judgements and accents. The word directed toward its object enters a dialogically agitated and tension-filled environment of alien words, value judgement and accents, waves in and out of complex interrelationships, merges with some, recoils from others, intersects with yet a third group: and all this may crucially shape discourse, may leave a trace in all its semantic layers, may complicate its expression and influence its entire stylistic profile [--] The word in language is half someone else's. It becomes one's "own" only when the speaker populates it with his own intentions, his own accent, when he appropriates the word, adapting it to his own semantic and expressive intention. Prior to this moment of appropriation, the word does not exist in a neutral and impersonal language [--] but rather it exists in other people's mouths, in other people's contexts, serving other people's intentions; it is from there that one must take the word, and make it one's own. (Bakhtin 1981, 276, 294.) 
These quotations sum up some of the principal characteristics associated with the Bakhtinian account of dialogism, such as utterance, value judgement, accent, social dialogue, alienation, and hybridisation. Beside the basic dialogic impulse of the author, in the case of Terveisiä Lapista it is prolific to attest dialogism in the high number of quoted passages the author uses for his pro and contra argumentation, in the interplay of different registers of Finnish (standard vs. dialect/spoken), and in the different languages involved (Finnish and very little Sámi, see Terveisä Lapista 87, 143, from now on TL). Moreover the topic of the book, the dialogic character of the chosen genre, the intercultural aspect of the plural address, as well as the interconnections between the original and its edited translations are further major aspects, which will be taken into account in the present analysis.

This kind of analysis has already been used by e.g. Coppélie Cocq in her article "Polyphony in Sámi Narrative" (2008). Cocq's article is devoted to Johan Turi's book Muitalus sámiid birra (1910) revealing also its various voices in Bakhtin's terms of polyphony and heteroglossia. The case of Terveisiä Lapista is, however, slightly different. Already Valkeapääs choice of the genre (pamphlet) leads the text to more intentional objectivisation of the "languages", i.e. to a more intentional choice of voices and their caricature. Besides, the fact of intentionality is stressed by the language of the text, namely Finnish and its dialects, and also the themes that are not limited to Sámi issues. Though the degree of intentionality may have reduced the applicability of Bakhtin's concepts intended for assessment and interpretation of novels, they can still serve at least as basic landmarks, when interpretatively approaching such stylistically hierarchical, incoherent and heterogeneous text as Terveisiä Lapista and revealing its languages and "languages" - only imitations of language.

The choice of genre and other narrative techniques (e.g. choice of tone, perspective, voice, temporal orientation, style) are special ways an author can create an invitation to dialogue. By frequently addressing the reader directly in the second person (both formally and informally), and by advertising the book's genre in large letters on the front cover (pamfletti), Valkeapää signals his desire to address the ongoing political processes inherent in dialogues between Finnish and Sámi voices. The numerous cited dialogues within the text itself can be interpreted as an overt call for dialogue, as shown by the twice-cited woman whose hyperbolic question acts as a significant gesture: "Ettekö Te todellakaan puhu Suomea [sic] ...” (TL 9) ("Do you really not speak Finnish?” Transl. JD \& MK). ${ }^{7}$ Here Valkeapää equates the Finnish reader with a petit bourgeois woman, whose cultivated speech and command of the Finnish language has convinced her of her own supremacy. Elsewhere a male, working-class Finnish voice appears, using offensive and vulgar speech (TL, 9; GL, 10). By quoting these diverse Finnish voices, Valkeapää [sic] upholds himself as a model representative of the Sámi: he is educated and eloquent, 
and he speaks better Finnish than the majority of Finns. At the same time, he enables readers to maintain their distance from these Finnish characters, since the intended reader is not presumed to be an arrogant, undereducated woman or a boor.

Valkeapääs writing style does not correspond to the intended reader, but it also may provide a key to the text in very definite sense. For example, the first chapter, "Viimeinen maa" ("The Farthest Land"), is written in a humorous style, showcasing common stereotypes of the Sámi people and the Sámi land. Such flagrant irony, revealing the preconceptions of the majority culture, forms a major part of the book. The next chapter, "Arktinen kulttuuri" ("Arctic Culture"), builds on the common cultural and somatic features of arctic peoples, while also focusing on the origin of the Sámi people. Both topics are treated in a serious, scholarly way; however, the scant features in their sketchiness are puzzling, as well as their phenomenological explanations - brought together with almost ethnical essentialism - seems to be contradictory.

Typically, Valkeapää only imitates the style of scientific discourse in order to show how inaccurate it can be for describing (other) people and (other) cultures. This inadequacy is most obvious concerning the origin of the Sámi people. On this topic, Valkeapää sets Western science against Sámi indigenous knowledge by mentioning the Sámi origin story, in which the people emerge as the product of a relationship between a Swedish princess and a dog (TL 16; GL 17). Since the Sámi tale is situated at the end of the chapter, it functions as a regressive corrective: it succeeds in conveying what Western science cannot. The tale itself is obviously ironic, as it answers the question of origin while also suggesting that this question is not of primary importance for the Sámi. Moreover, by juxtaposing the noblest and lowest elements of Sámi culture in a carnivalesque fashion, the tale highlights their ability to anticipate and ridicule the expectations of the majority.

A similarly fanciful treatment of the Western concept of cultural prestige is shown in the chapter "Lappi" ("Sámi land"), which contrasts Western "high" culture and Sámi "primitive" culture through the sentence "Jo muinaiset roomalaiset tiesivät Lapin olemassaolon" (TL, 17). This sentence, translated later into English as "The ancient Romans were already aware that Sámiland (Laponia) existed" (GL 17), is followed by a list of other peoples who were also familiar with Sápmi and the Sámi. The list is, in a way, heterogeneous - it includes not only nations in the modern sense (such as English or Dutch), but also groups defined by political, religious, and topographical features: Kvens, Karelians and White Sea Karelians, and Danish-Norwegians, but also social groups such as the Birkarls. In this chapter, as well as throughout the book, irony is employed as the basic deconstructing device, and it derives from the contrast of diverse social levels, which can be categorized in the following way: 
- the contrast between high-minded pedantic statements suggesting the Sámi's direct links to Western civilization, such as "already the ancient Romans knew", and base motifs of conquest, such as: "Because they represented more populous and mightier cultures, they were able to set out in their plundering raids" (GL, 18; TL, 17.)

- the contrast between the "high culture" of the Scandinavian colonizers and their aggressive violations of Sámi culture: ”The magic drums were smashed in the intoxication of ravaging ... So it was a good thing to live for enlightenment and culture. And for the priest. And for the robbers" (GL, 19; TL 17.)

- the contrast between well-known people, like the Romans, and obscure groups such as the Karelians or Birkarls, is analogous to the long-documented comparison of the Sámi to the "lesser-known" Finns. The author states that, "During those days the Finns had quite enough to do with finding their own identity," and goes on to repeat the famous slogan of the Finnish identity quest of that time: "we aren't Swedes, we don't want to be Russians - let's be Finns!" (GL, 20; TL 19.)

As with most of the chapters, "Saamelainen" ("The Sámi") is built upon similar types of contrasts. This time, Valkeapää lists classical historians and topographers who knew the Sámi, the Swedes, and the Balts, but again not the Finns. The ironic depictions of intercultural dialogue are mostly related to issues of religion and legality-mostly at the expense of Finnish culture. As Valkeapää later explains in chapter "Kristus" ("Christ"), if the ancient singing tradition of yoiking were actually witchcraft, so too would be Lutheran pastors' expressive preaching during polar nights, which gives rise to dispiritedness and Christian iconoclasm, and therefore should also be forbidden by law.

If Finnish culture can be favorably compared to Sámi culture from the Finnish point of view (in terms of reputation, length of history, morality, heroism, legitimacy of religious practice, etc.), then modern Sámi culture could also be compared to Finland's Swedish culture. Following the above-mentioned essentializing list of similarities between arctic cultures (nomadic tents, sledges, lassos, etc.), Valkeapää offers his own confession about the vitality of the Sámi culture and his position in it: "My people can evaluate everything I do; if they accept it, that's fine. If not, I am a spiritual refugee from a country which doesn't exist." (GL, 57; TL 62). Does this statement express Valkeapääs hope that Sámi culture is not dying out, due to its inability to accept new influences from the outside or from within the community? Or is it possible to read Valkeapääs statement as an allusion to Edith Södergran and, by extension, to the exclusive position of Swedes in Finland? After all, Swedish culture forms a part of Finnish culture, and Finland Swedes are regarded as an essential part of the urban Finnish "high society". In order to oppose them, Finns used to dress themselves like the Sámi and build "Sámi" villages, but only for profit, as Valkeapää points out. Furthermore, from the stand- 
point of the present-day, it is obvious that Valkeapää and his culture have succeeded in bridging the past and the present, but at the time Terveisiä Lapista was published, this outcome was far from guaranteed.

It seems that Valkeapää has more accurately described the perspective of Finns than that of the Sámi, since he is basically the only Sámi whose experiences are quoted in the book, and whose voice can be heard. Even in the book's frequent quotations of scientific literature and historical sources, which appear in italics between chapters, there is scant indication that the text was originally written by a Sámi. Only Valkeapääs observations about the ways the Sámi look and speak (quoted above), along with the personal names listed on page 87 of Greetings from Lapland, reveal a Sámi author. These instances, together with the ironic repositioning of Finnish culture, enable Valkeapää to engage in dialogue with the various social orders represented in this book.

\section{Translations as further attempts at intercultural dialogue}

The environmental destruction of the twentieth century in Sápmi included among others, for example, the damming of over 100 rivers in the Sámi ancestral lands of Norway, Sweden, Finland, and Russia. Along with it, the massive expansion of tourist infrastructure (consisting of roads, parks, hotels, recreation areas, etc.), industrialization, technological developments, and the radical cultural assimilation of the Sámi, all formed together the backdrop to Valkeapääs polemic. As Valkeapää confesses in his foreword to the Norwegian (1979) and English (1983) editions, this handy Finnish book did open up discussion on Sámi issues in Finnish society, but the dialogue was not extensive enough. As it is well known, it would be nearly two more decades before any effective political dialogue was established between the Sámi and Finnish officials.

But in the meantime, in Norway, things took a much radical turn. At the end of the 1960s the Norwegian State Energy Company created a proposal for the ÁltáGuovdageaidnu watershed, which included the flooding of large areas, and even the village of Máze (cf. Lehtola 2010, 70-77). Controversy raged around these plans for over a decade. While some Sámi supported Sámiid Ædnansarvi (the Norwegian Sámi Union) and demonstrated in support of the parliamentary decision, others (such as Norgga Boazosápmelačcaid Riikasearvi, the Reindeer Herders' Association of Norway, or Norgga Sámiid Riikasearvi, the National Organization of Sámi in Norway) gathered together not only to fight against the aggressive policies of the state, but also to raise awareness of the issue in their community. Being well connected internationally, Valkeapää played also an important role in the ideological articulation of the latter group. As he later admits in the prologue to the Norwegian edition:

At this time in Finland, a "pamphlet period" prevailed, characterized by the publication of small, crudely made books. This period coincides with the advent of public discussion about the Sámi people's position in Finnish society. ${ }^{8}$ (Valkeapää 1979, 9; transl. Liv Hatle.) 
In 1979, at the height of the Áltá Damm conflict, when both the Sámi and the Norwegians were divided in their opinions, the radical publishing house Pax Forlag printed Valkeapääs politisk revy ('political revue') in the Norwegian Nynorsk language. The book's translator, Liv Hatle, remarks in her short preface that in the course of editing the book, or more precisely adapting it to the Norwegian reading audience ${ }^{9}$, many of the immediate references to local politics were omitted and new chapters were introduced, including the introductory chapter, "Åtvaring" ("Warning"), three chapters in the middle of the book, "Nomadisme" ("Nomadism"), "Kunst" ("Art"), and "Sameparlamentet" ("Sámi Parlament"), as well as the closing two chapters, "Fugeln må avlivast..." ("A bird must be euthanized...") and "Ein fugl i hjarta" ("A bird in the heart"). In order to create space for 30 pages of new material, nearly 20 pages were cut from the Finnish original (including the chapters "Suopunki," "Tomaatti," "Lantalainen," "Jälkikirjoitus," and "Anna Liisa"). ${ }^{10}$ In this way, the Finnish-Sámi conflict from the original text is cast as part of a general conflict between Nordic and indigenous peoples, and it situates the author at the center of both local and global indigenous struggles. The added material contains even more quotations from local and foreign authors (mostly anthropologists and political activists), which, rather than complicating the author's argument, gives the text a patchwork character. This must have been due to the time constraints Valkeapää was under in finishing the book. Remarking on the timeline of the translation, Liv Hatle relates in an e-mail:

When I saw his book, I got the idea of translating it into Norwegian. While translating the book, I went to Kaaresuvanto to meet Áillohaš. There we worked on the text. We removed what had no relevance for a Norwegian reader, and he (we) added some new texts. I presented the translation for a Norwegian publisher, and the book Helsing fra Sameland got published in 1979. That was "Áltá-time", and the book spread widely. Very soon it was sold out. (Hatle 21.01.2015.)

Knowing Finnish very well, and being familiar with Sámi culture and political issues, as well as having excellent Norwegian language skills, Liv Hatle proved to be not only an excellent translator but a sharp editor as well. By preserving the original Finnish terms on the five included maps, and by placing the Norwegian translations below the maps, the Norwegian version of Valkeapääs work maintains a connection to the original edition. Moreover, because the additional texts are absent from the original 1979 edition, it is worth considering Helsing fra Sameland as a source text in and of itself, rather than merely a translation. Besides pointing out the linear structure of the chapters and introducing of new chapters, the comparative table nr. 1. at the end of this paper indicates the locations of the maps within the book. Since no relevant changes occurred in this regard between the Finnish and the Norwegian editions, but did occur in the English and German editions, it is worth considering the differences of these visual materials as well. 


\section{Greetings from Lapland (1983, transl. Beverly Wahl)}

By the late 1970s and early 1980s the political events regarding the Áltá-Guovdageaidnu watershed escalated even further, which no doubt provided the impetus for the English translation. Describing the whole process in detail in his book The Sámi People, Veli-Pekka Lehtola recounts that:

The decision, made in September 1980, to continue building the road prompted the demonstrators to set up a permanent camp in Stilla. [--] After the forced removal of people from Stilla at the end of January 1981, ten Sámi [--] went on hunger strike in front of the main entrance to the Storting building [Parliament] in Oslo. [--] In March 1982 the situation took a dramatic turn. Two Sámi tried to blow up a bridge on the part of the bridge that had already been built. The photographer Niillas A. Somby lost a hand when he pressed the detonator too soon. Sámi reaction to this act of defiance was conflicting. (Lehtola 2010, 76-77.)

Helsing fra Sameland served as the source text for the English version made by Beverly Wahl, an English translator living in Norway. Just as Liv Hatle was part of Valkeapääs circle of friends and acquaintances (she even performed several times together with Valkeapää/Áilu), Beverly Wahl also became involved in the translation effort through personal contacts. Her translation was published in 1983 by Zed Press of London, a self-described "radical international publishing house". By illustrating the chapters with 28 photographs by the Sámi artist Niillas A. Somby (b. 1948), the English publication showed a gesture of support for the photographer, who was on trial at the time. Wahl notes in the book's two-page foreword:

The acute reader will notice that virtually all of the pictures have been taken in Norway, during the recent upheavals here, and that the photographer is officially Norwegian (though presently seeking political asylum in Canada). Again, it's all a matter or definition, and who does the defining, and NilsAslak Valkeapää and Nils Somby are close friends and neighbors; they just happen to live on opposite sides of a river which the Norwegians and Finns decided to call a boundary. (Wahl 1983, ii.)

After disclosing why the ethnonym of Sámi is used in lieu of the better-known English form of Lapp, and explaining the preference for the original Sámi place names (though they are not used consistently), the translator mentions why the explanatory footnotes were necessary in the text. ${ }^{11}$ Aside from these informative footnotes, the photographs of Nils Somby are all tagged with titles, which can be interpreted as summaries of the authorial message. These titles consist of sentences often ending in ellipses, which lead the readers to view the photos not only from the perspective of the author, but also from that of the whole Sámi community. These titles can be grouped into five different categories that either highlight the conflicts between the Sámi and the colonizers/Nordic majorities (Group 1-3), work towards the articulation of the Sámi 
as a unified community (Group 4), or voice the shared fate of the Sámi and other indigenous people (5). Though always combined in a chapter, these three major motifs also correspond to three parts of the book: chapters 1-15, chapters 16-27 and chapters 28-29.

1. The largest group of titles addresses the ignorance created by hegemony of Western/ Nordic countries over the indigenous Sámi. For example:

"In Western Europe people believe that the land we live in..." "...is wild and uninhabited." (GL, 8, 12.)

"But the world doesn't end at the upper edge of the map." (GL, 14.)

"They sent us their school medicine from the "enlightened world." We have our folk medicine from days of old, which the arrogant call quackery." (GL, 64.)

"Christ was one of the colonialists' most vital weapons - so was the bottle." (GL, 67.)

"The impenetrable fences of industrialism bring with them death and destruction." (GL, 120.)

2. The titles belonging to the second group aid in interpreting Nordic history from the perspective of the Sámi:

"Our people live off reindeer husbandry, farming, hunting and fishing. We were colonized and now we are divided between Norway, Sweden, Finland and the Soviet Union." (GL, 18.)

"We're a non-violent people. The "dažžz" came with his military violence and colonized us." (GL, 23.)

"We have lived in Sámiland since the dawn of time, and we live and dwell here still..." (GL, 28.)

"My heart weeps blood when the Vikings come to rob us of our land." (GL, 50.)

"The sword pointed at the Sámi people can take many forms..." (GL, 69.)

3. The third group addresses points of conflict between the Sámi and Western/Nordic societies, mainly due to cultural differences, but also because of different economic and political interests:

"Reindeer husbandry is one of the most profitable and natural livelihoods in Sámiland, but the majority is interfering..." (GL, 34.)

"Traditionally, wolves are reindeer husbandry's greatest enemy, but the majority society is a greater enemy..." (GL, 42.)

"The buoddu, our ancient method of fishing, provides the people with salmon. The Finnish sports-fishers would like to see it forbidden... for their fiberglass fishing rods to be used in their leisure time." (GL, 52.)

"The [school] instruction offered is ill suited to our needs ... few youngsters find any use for it." (GL, 74.)

4. In addition to constructing "what the Sámi are" by defining what they are not, Valkeapää also helps to raise the Sámi dignity from within. These titles describe Sámi values: 
"Yoik - our music - and drums were a way of making contact with the spirits." (GL, 56.)

"Our Sámi language belongs to the Finno-Ugric language group, it is a most vital part of the cultural heritage bequeathed by our forefathers." (GL, 79.)

"To my great joy, I have discovered that those Sámi youth who haven't been Swedicized, Finnicized, or Norwegianized have radically changed their course ... all that is Sámi they regard highly." (GL, 126.)

5. As the closing chapters of the book concentrate on the relationship between the Sámi and their fellow indigenous peoples, the title of a photo showing Valkeapää and a Native American artist performing on the horn and panpipes underlines the political relevance of such relations:

"We have natural alliances in other parts of the world, we should consolidate them - we can support them, they can support us. Then we are not just few, but a big majority." (GL, 116.)

The overwhelming use of the first-person plural pronoun "we" and the possessive pronoun "our," along with the accompanying verbs in the first-person plural, places the indigenous community into a closer, more emphatic relationship with the reader. On the other hand, when the pronouns "they" and "them" are used with verbs in third-person plural, it creates a reflective distance between the reader to the deeds of "civilized" societies. Although the "we" never extends to the subjective tone of the narrator, one can infer an additional meaning wherever the first-person singular pronoun and possessive pronoun appears in the text. These moments are loaded with emotion, implying a strong call to the author's own people ("please look at it, and notice it").

Not only does the English version differ from the Norwegian one in terms of its footnotes, titled photographs, and extensive foreword, but there are three additional changes as well. By cutting out one chapter ("Dokketeatter," "Puppet Theater"), the editor changed the number of chapters in the English version from 29 to 28 . The alteration of two chapter titles also causes a shift in the reader's focus: "Miekka/Sverdet (Sword)" was translated as "The Law," and "Puoskari/Kvaksalvaren (Charlatan)" was translated as "Healing".

\section{The text of Valkeapää still "on the move"}

Sámi culture has made a breakthrough in the Nordic countries in the recent decades. However, its breakthrough in other European countries, and on the world stage, is still to come. Barring a revival of the pamphlet genre, there are several opportunities for smaller cultures to make their voices more clearly heard. On the subject of these translations, Osgood Dana aptly remarks: 
In 1983 an English translation from the Norwegian by Beverly Wahl was issued by Zed Press in London, intended for a world audience (Greetings from Lapland: The Sámi Europe's Forgotten People). Zed Press had been set up in 1976 with the aim of creating a significant Third World publishing house which would enrich socialist literature in the English language broadly antiimperialist and supportive of liberation movements. Originally, a profoundly personal political statement, Terveisiä Lapista became part of the larger political protest movement in its Norwegian translation, and in its third language, Greetings from Lapland had become more and more politicized. (Dana 2003, 72.)

In 2014 yet another translation was completed, though it will only be briefly discussed below due to the involvement of the authors of this paper. The recent German translation aimed to contribute to the spread of information on Sámi culture outside of Scandinavia, and it was published at the 2014 Frankfurt Book Fair, when Finland was the guest of honor. Thekla Mäus pointed out in her 2013 article that only three books by Sámi authors have appeared in German translation in the past three decades. Though the real number is actually six (one book by Valkeapää and Kirste Paltto, two by Áilu Gaup, and two editions of a work by Johan Turi), it is nonetheless a very low number for such a large reading audience. The other two translation books published on Sámi topics for the Bookfair (Veli-Pekka Lehtola: Die Sámi. Traditionen im Wandel, Rauni Magga Lukkari and Inger-Mari Aikio-Arianaick: Ermütter - Welttöchter) grow in significance due to the rarity of Sámi books in the "world language" of German.

The German translation Grüße aus Lappland (Samica, Vol. 1), made by a group of students at Bielefeld University, used mainly the English version as source text, but in the course of the final editing made use of the Finnish-language original as well. Here Valkeapääs pamphlet was framed by a foreword by the editor, Johanna Domokos, as well as an epilogue by the team of translators, known collectively as Gruppe Bi. The nine-page "Author's Introduction" from the English version was also included. In fact, this was the main reason behind the translators' choice of the English text as a primary source. Since the English version did not include the chapter "Dokketeater" ("Puppet Theater," or "Nukketeatteri" in Finnish), the German version also omitted it - moreover, events cited in that chapter were of local interest and of local relevance. Since the photographs from the original text were no longer available to digitize, the German edition included only the maps (see the comparative charts at the end of the paper).

\section{Closing thoughts}

The theme of Terveisiä Lapista is the majority approach to Sámi culture and rejection of cultural and social hierarchy based on ethnic categories. The Sámi traditional voices are deprived of their defensiveness in the heteroglossia of Western ideological languages, as it is not advocated by the mere notion of tradition, but by its pragmatism and adequacy. On the other side, the Western voices lose their presumed exclusivity. The theme itself- 
as a relational category - makes the book inapt for re-editions in terms of ethnographic series (unlike Turi's Muitalus sámiid birra), but when it is placed into wider political or new period contexts while stressing the non-Sámi side of the relation, the translations could have been published as a contribution to general political changes that have not been finished yet. In a way, Terveisiä Lapista, a text making Western voices speak to be quieted again, can be taken as a counterpart or overture to Valkeapääs own monophonic poetry intended primarily for the Sámi and the indigenous audience, since others are only allowed to look at the reflections of the pictures (cf. the editions of Valkeapääs poetry in translations, especially the missing photographs).

The dialogic power of Nils-Aslak Valkeapääs Terveisiä Lapista has not been lost throughout the decades. Written in a touching style, where the reader is involved on many levels, it can be read with excitement even today. Although the conditions of the Sámi have improved greatly since the book's publication, people interested in Sámi issues can easily perceive the conflicts caused by the encroachments of Nordic and global culture. Since Valkeapääs Finnish-language original was heavily edited in the process of being brought to other cultures and other readers, the Norwegian and English editions can be interpreted as original textual sources in themselves, which in turn can give birth to future translations. The author was aware of the necessity of editorial changes in order for his book to accompany the reader in space and time.

Due to the author's untimely death at age 59, the text cannot be edited further. But in order to keep his spirit alive, it is absolutely necessary to republish his works again and again, in any language necessary.

\section{References}

${ }^{1}$ We, the authors, wish to thank the Otava Publishing House (for granting us access to the Finnish original), the Lásságammi Foundation (for assisting us with questions on manuscripts), and especially Liv Hatle, for answering all of our questions.

2 "I can just briefly mention that the memorial to President Kekkonen was raised, against the Sámis' will, on the peak of Saivvarri, right in the middle of reindeer pastureland. Thus it became a symbol of Finnish colonialism. Sámiland is full of the great marks of colonialism anyway, you can see them on the map. One of the greatest will be the Alta power station." (Valkeapää 1983, 3.)

${ }^{3}$ http://issuu.com/ihmeproductions/docs/ihme_2014_true_finn_issuu (1.8.2015).

${ }^{4} \mathrm{http}$ ://www.finlit.fi/fili/hallinta/wp-content/uploads/2014/09/Finnland.-Programme.pdf (1.8.2015).

5 The title is written both on the hard cover as well as on the title page inside of the book in the following way: terveisiä LAPISTA plus specifying its genre: pamfletti. However we will cite this work as all other secondary sources do, as Terveisiä Lapista.

${ }^{6}$ For the general characteristics of this genre see e.g. Galchinsky 2012, 1025-1034.

${ }^{7}$ For the sake of clarity, all quotations in Finnish and Norwegian will also provide the English translation. 
8 "I Finland rådde på den tida ein pamflettperiode. Små bøker dukka opp, og i desse uttrykte ein seg så uforskamma som ein berre kunne få seg til. På same tid byrja og i Finland den offentlege diskusjonen om samefolket si stilling i samfunnet." (Valkeapää 1979, 9; the English translation JD \& MK).

9 This act is definitely worth analysing within the theoretical framework of adaptation by Hutcheon (2006) in the future.

${ }^{10}$ See chart nr. 1 comparing the table of contents of Terveisiä Lapista and Greetings from Lapland at the end of the article.

11 " [-- elucidations for an English-speaking (or reading) public mainly take the form of explanatory footnotes, where we felt a reference was too obscure for non-Nordic readers, and the author's introduction. [--] I am deeply in debt to Liv Hatle, who has given up so much of her time to discuss comparative linguistics (Finnish, Norwegian and English) with me, and to orientate me on Finnish affairs." (Wahl 2010, i,ii.)

\section{Bibliography}

Primary sources:

Valkeapää, Nils-Aslak 1971. Terveisiä Lapista. Pamfletti [= TL]. Helsinki: Otava.

Valkeapää, Nils-Aslak 1979. Helsing frå Sameland. Transl. Liv Hatle. Oslo: Pax Forlag.

Valkeapää, Nils-Aslak 1983. Greetings from Lapland. The Sámi Europe’s Forgotten People [= GL]. Transl. Beverley Wahl. London: Zed Books.

Valkeapää, Nils-Aslak 2014. Grüße aus Lappland. (Samica, Vol. 1). Hrsg. Johanna Domokos. Übersetzt von Johanna Domokos \& Gruppe Bi. Freiburg: Skandinavisches Institut der Uni Freiburg.

\section{Secondary sources:}

Bakhtin, M. M. 2000 (1929). Problemy tvorchestva Dostoevskogo. S. G. Bocharov \& L. S. Melikhova (eds), Sobranie sochinenii. Moskva: Russkie slovari, vol. 2, 5-175.

Bakhtin, Mikhail 1981 (1934/1935). Discourse in the Novel. The Dialogic Imagination. Four Essays. Austin: University of Texas Press, 259-422.

Bakhtin, Michail 1984 (1963). Problems of Dostoevsky's Poetics. Manchester: Manchester University Press.

Cocq, Coppélie 2008. Polyphony in Sámi Narrative. Journal of Folklore Research 48, 2, 193-228.

Galchinsky, Michael 2012. Political Pamphlet. Burwick, Frederick (ed.), The Encyclopedia of Romantic Literature. DOI: 10.1111/b.9781405188104.2012.x. Blackwell Reference Online.

Hatle, Liv 2015. E-mail messages from January to April 2015, addressed to Johanna Domokos.

Keskinen, Suvi, Salla Tuori, Sari Irni \& Diana Mulinari (eds) 2009. Complying with 
Colonialism: Gender, Race and Ethnicity in the Nordic Region. Surrey, Burlington: Ashgate.

Lehtola, Veli-Pekka 2010 (2002). The Sámi People. Traditions in Transition. Transl. Linna Weber Müller-Wille. Inari: Kustannus-Puntsi.

Lehtola, Veli-Pekka 2012. Saamelaiset suomalaiset-kohtaamisia 1896-1953. Helsinki: SKS.

Lundquist, Suzanne 2004. Native American Literatures. An Introduction. New York \& London: Continuum.

Musäus, Thekla 2013. Finnische Literatur in deutscher Übersetzung. Marja Järventausta \& Marko Pantermöller (Hrsg.), Finnische Sprache, Literatur und Kultur im deutschsprachigen Raum - Suomen kieli, kirjallisuus ja kulttuuri saksankielisellä alueella (Veröffentlichungen der Societas Uralo-Altaica, Band 85). Wiesbaden: Harrassowitz, 353-370.

Osgood Dana, Kathleen 2003. Aillohaš the Shaman-Poet and his Govadas Image Drum. A Literary Ecology of Nils-Aslak Valkeapää (Acta Universitatis Ouluensis. Series B. Humaniora 50). Oulu: Oulun yliopisto.

Wahl, Beverly 1983. Translator's Foreword. Valkeapää, Nils-Aslak. Greetings from Lapland. London: Zed Books, i-ii. 


\section{Comparative charts}

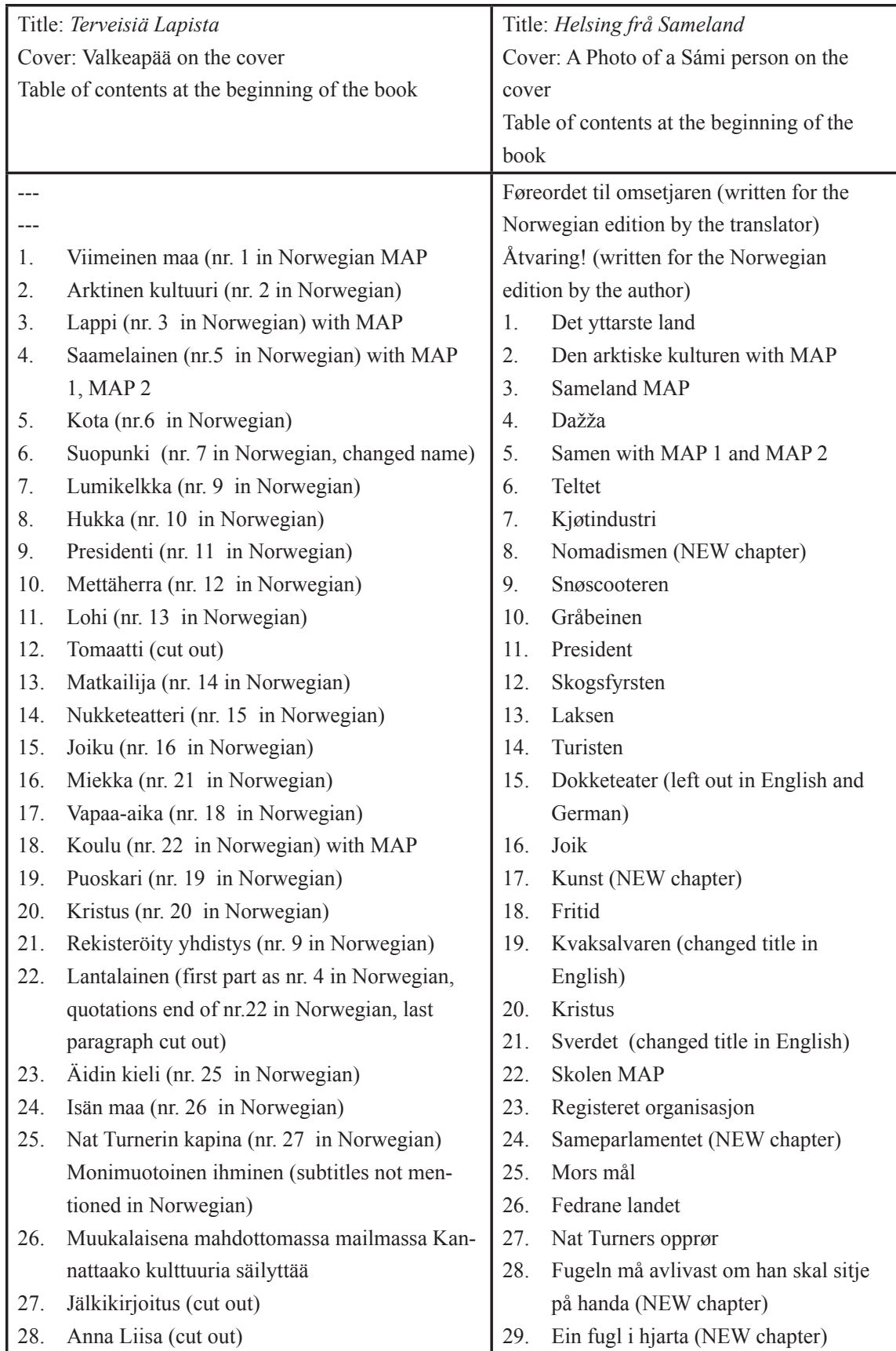

Table nr. 1. Comparative Chart of table of contents of Terveisiä Lapista and its Norwegian translation 


\begin{tabular}{|c|c|}
\hline $\begin{array}{l}\text { Title: Greetings from Lapland. The Sámi-Eu- } \\
\text { rope's forgotten people } \\
\text { Cover: Drawing of the author } \\
\text { Table of contents at the beginning of the book }\end{array}$ & $\begin{array}{l}\text { Title: Grüsse aus Lapland } \\
\text { Cover: Arealis borealis photo, author's photo on } \\
\text { the second page } \\
\text { Table of contents at the beginning of the book }\end{array}$ \\
\hline $\begin{array}{l}\text { MAP } \\
\text { Translator's Foreword } \\
\text { Author's Introduction } \\
\text { PHOTO } \\
\text { 1. The Farthest Land } \\
\text { 2. Arctic Culture, with } 2 \text { PHOTOS } \\
\text { 3. Sámiland, with PHOTO } \\
\text { 4. Daccas, with PHOTO } \\
\text { 5. The Sámis, with MAP and PHOTO MAP } \\
\text { 6. The Tent } \\
\text { 7. The Meat Industry, with PHOTO } \\
\text { 8. Nomadism, with PHOTO } \\
\text { 9. The Snow-Scooter, with PHOTO } \\
\text { 10. Wolves, with PHOTO } \\
\text { 11. The President } \\
\text { 12. Lord of the Forest, with PHOTO } \\
\text { 13. The Salmon, with PHOTO } \\
\text { 14. The Tourist, with PHOTO } \\
\text { 15. Yoik, with PHOTO } \\
\text { 16. Art, with PHOTO } \\
\text { 17. Leisure } \\
\text { 18. Healing, Then and Now, with PHOTO } \\
\text { 19. Christ, with PHOTO } \\
\text { 20. The Law, with PHOTO } \\
\text { 21. Schooling, with MAP and } 2 \text { PHOTOS } \\
\text { 22. Mother-Tongue, with PHOTO } \\
\text { 23. Fatherland, with PHOTO } \\
\text { 24. Registered Organisations, with PHOTO } \\
\text { 25. Sámi Parlament, with PHOTO } \\
\text { 26. Nat Turner's Rebellion, with PHOTO } \\
\text { 27. The Bird hast to be Killed to get it to Sit } \\
\text { on Your Hands, with } 2 \text { PHOTOS (one with } \\
\text { 28. } \text { Aalkeapää) } \\
\text { Bird in my Heart, with PHOTO }\end{array}$ & 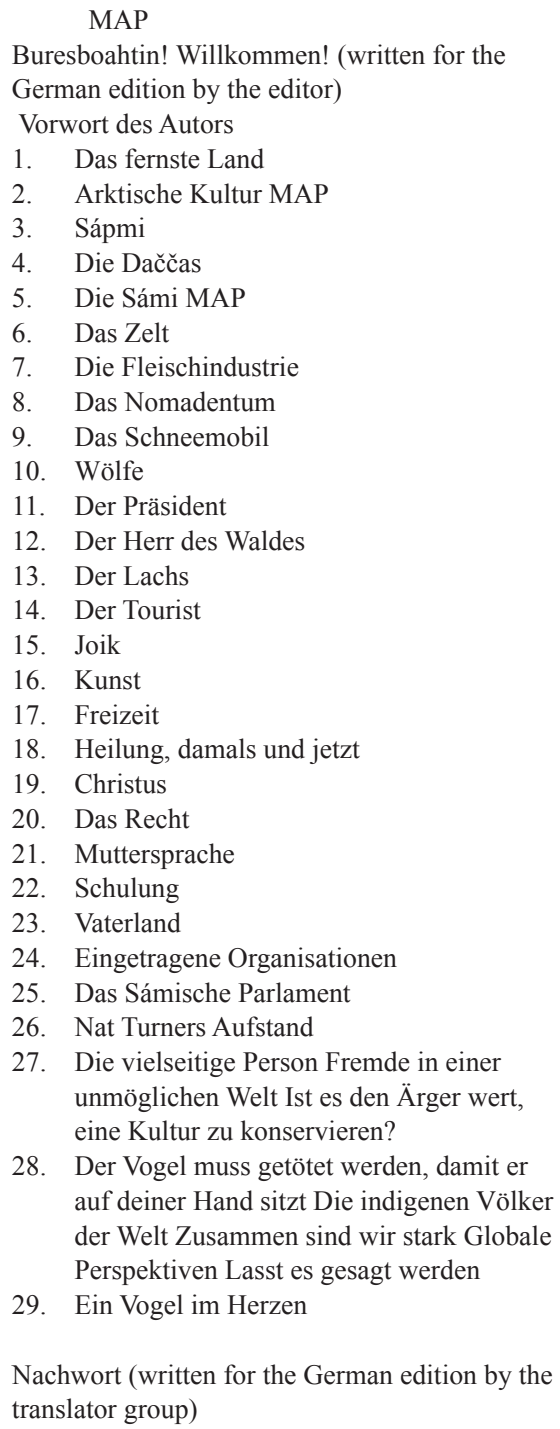 \\
\hline
\end{tabular}

Table nr. 2 Comparative Chart of table of contents of the English and German translation 